Jolanta Judyta Pudełko PDDM

\title{
AARON JAKO NAUCZYCIEL ŚWIADECTW (SYR 45,17)
}

\section{Aaron as a Teacher of Testimonies (Sir 45:17)}

\begin{abstract}
In the Greek version of the Book of Sirach the term $\mu \alpha \rho \tau u ́ p ı \nu$ (testimony) appears twice. Besides Sir 36:14, the word appears also in the Praise of the Ancestors in reference to Aaron (Sir 45:17). Moses' brother is described there as the one

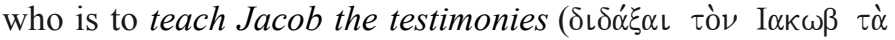
$\mu \alpha \rho \tau v ́ \rho(\alpha)$, an expression that is missing from all other Biblical texts referring to Aaron. Therefore, the context of this expression, i.e. the praise of Aaron in Sir 45:6-22, is first analyzed and then various textual versions of Sir 45:17 are compared. Understanding the meaning of the term testimony in this context is made possible by the analysis of this word in other Biblical contexts, both those connected with the history of Aaron and the Sinai covenant as well as other, unrelated texts. Finally, the expression referring to Aaron is placed within the times of Sirach and those of the translator of the Greek version of the book. The key to understanding Sir 45:17 is found in the function and significance of the post-exile high priest. He is - as understood in the Book of Sirach - the only mediator between God and his people, and thus becomes the living symbol of covenant, responsible for transmitting testimonies: the Word of God, the content and requirements implied by the covenant made with God.
\end{abstract}

Keywords: biblical theology, Book of Ben Sira, The Praise of Ancestors, Aaron, priesthood, testimony, witness 
Streszczenie: W greckiej wersji Księgi Syracha dwukrotnie

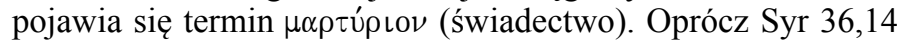
pojawia się w Pochwale ojców w odniesieniu do osoby Aarona (Syr 45,17). Brat Mojżesza zostaje tam określony jako ten,

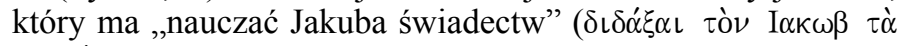
$\mu \alpha \rho \tau u ́ \rho \iota \alpha)$. Taka wypowiedź nie pojawia się w innych tekstach dotyczących Aarona w Biblii. Zostaje więc najpierw przeanalizowany kontekst tej wypowiedzi, a mianowicie pochwała Aarona zawarta w Syr 45,6-22, a następnie porównane wersje tekstualne Syr 45,17. Zrozumienie znaczenia terminu ,świadectwo" w tym kontekście, staje się możliwe dzięki analizie tego słowa innych kontekstach biblijnych związanych z historią Aarona i przymierza synajskiego oraz niezależnymi od niej. W końcu wypowiedź dotycząca Aarona zostaje osadzona w czasach Syracha i thumacza greckiej wersji księgi. Kluczowym dla zrozumienia Syr 45,17 staje się przedstawienie funkcji i znaczenia powygnaniowego arcykapłana. Jest on w rozumieniu Księgi Syracha jedynym pośrednikiem między Bogiem i ludem, znakiem przymierza, odpowiedzialnym za przekazywanie świadectw - Słowa Bożego, treści i wymagań wynikających z zawartego z Bogiem przymierza.

Słowa kluczowe: teologia biblijna, Księga Syracha, Pochwała ojców, Aaron, kapłaństwo, świadectwo

W greckiej wersji Księgi Syracha dwukrotnie pojawia

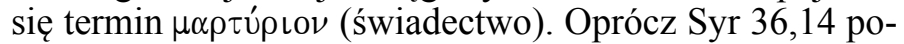
jawia się w Pochwale ojców w odniesieniu do osoby Aarona (Syr 45,17). Brat Mojżesza zostaje tam określony jako ten, który ma „nauczać Jakuba świadectw” ( $\delta\left\llcorner\delta \alpha \xi_{\alpha \iota} \iota \grave{\nu} \nu\right.$ I $\alpha \kappa \omega \beta \tau \dot{\alpha} \mu \alpha \rho \tau u ́ \rho \iota \alpha)$. Aby zrozumieć tę wypowiedź, która nie pojawia się w innych tekstach dotyczących Aarona, spróbujemy w sposób ogólny przyjrzeć się kontekstowi tej wypowiedzi, a mianowicie pochwale Aarona zawartej w Syr 45,6-22. Następnie analiza dotyczyć będzie badanego tekstu Syr 45,17 oraz różnic między jego wersjami tekstualnymi. Zrozumienie znaczenia terminu ,świadectwo" w tym kontekście, ułatwi również przyjrzenie się temu słowu w innych kontekstach związanych $\mathrm{z}$ historią Aarona oraz nienależącymi do niej. W końcu wypowiedź 
dotycząca Aarona zostanie osadzona w czasach Syracha i tłumacza greckiej wersji księgi oraz zestawiona z ówczesnym obrazem arcykapłana.

\section{Pochwala Aarona w Księdze Syracha (SYR 45,6-22)}

Syr 45 rozpoczyna się od pochwały Mojżesza, któremu mędrzec poświęca jedynie pięć wersetów ${ }^{1}$. Jest on ukazany jako człowiek umiłowany przez Boga i ludzi, wierny i łagodny (45,1.4, por. Wj 33,11; Lb 12,7-9; Pwt 34,11), sprawca wielkich znaków. Przez niego dokonało się wyjście z Egiptu $(45,3)$, to on doświadczył Bożej obecności i bliskości oraz przekazał Boże przykazania $(45,5)$. Jednak Syrach przedstawia Mojżesza bardzo powściągliwie i nie uwypukla przymierza synajskiego, którego pośrednikiem był właśnie Mojżesz. W Syr 45,6 rozpoczyna się natomiast pochwała Aarona, która zajmuje aż 17 wersetów ${ }^{2}$. Cały fragment Syr 45,6-22 można podzielić na kilka części:

45,6-7c: przedstawienie Aarona

45,7d-14: strój i posługa Aarona

45,15: wprowadzenie w czynności arcykapłana

45,16: wybranie Aarona

45,17: odpowiedzialność prawna Aarona

45,18-22: troska Boga wobec Aarona ${ }^{3}$.

Opis Aarona rozpoczyna się od przedstawienia jego osoby w odniesieniu do Mojżesza $(45,6)$. Autor podkreśla jego wywyższenie i świętość ${ }^{4}$, podobną Mojżeszowi, któ-

${ }^{1}$ Zob. na ten temat: Skehan - Di Lella, The Wisdom of Ben Sira, 510; Witte, „Mose”, 161-186.

${ }^{2}$ Opis Aarona odnosi się bezpośrednio zarówno do jego osoby, jak i do urzędu arcykapłana, co znajdzie swój wyraz w przedstawieniu arcykapłana Szymona (Syr 50). Por. Wright III, „The Use”, 195; Rivkin „Ben Sira”, 97*.

${ }^{3}$ Por. Reiterer, „Aaron's Polyvalent Role”, 28-29.

${ }^{4}$ Syr 45,6 ma różnice w wersjach tekstualnych. Podkreślenie świę-

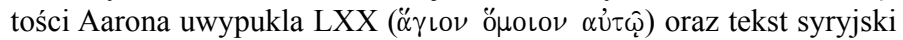


rego świętość potwierdza Ps $106,16 \mathrm{~b}$ oraz w Lb 16,1-75. Aaron jest przedstawiony jako brat Mojżesza (por. $\mathrm{Wj}$ 6,20), pochodzący z rodu Lewiego (por. Wj 6,16-20; Lb 26,57). A zatem mędrzec $z$ jednej strony podkreśla pochodzenie Aarona i jego więź z Mojżeszem, z drugiej strony - jego szczególne wybranie przez Boga. Tę kwestię pogłębia kolejny werset $-45,7 \mathrm{ab}$. Jest tutaj mowa o wiecznym przymierzu zawartym z Aaronem i o darze kapłaństwa, jaki przypada w udziale jemu i jego potomstwu ${ }^{6}$. Autor chce tu podkreślić nieodwołalność Bożego postanowienia względem Aarona i jego potomków ${ }^{7}$. Godność i dar Boga udzielony Aaronowi stają się przyczyną jego chwały $\mathrm{i}$ autorytetu, co potwierdzają w $45,7 \mathrm{bc}$ wersje $\mathrm{H}$

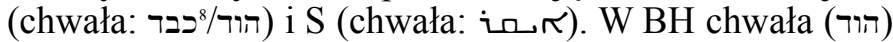
należy do Boga (por. Ps 8,2; 96,6), udzielona Mojżeszowi zostaje przekazana Jozuemu (por. Lb 27,20-23), jest też udziałem króla Salomona (1 Krn 29,25), a nawet przyszłego mesjasza (por. Za 6,13). Nie jest ona jednak odnoszona do Aarona czy jego potomków. Wersja G chwałę łączy

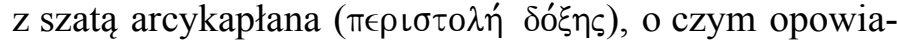
da kolejny fragment tekstu: 45,7d-149. Według Wj 28,2 Mojżesz przygotowuje dla Aarona i jego synów szaty kapłańskie, w tekście Syracha czyni to sam Bóg ${ }^{10}$. W tekście H Syr 45,7d pojawia się odniesienie do „rogów bawołu”

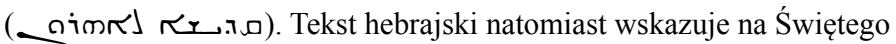
(Boga), który wywyższa Aarona (וירם קדש את אהרן).

${ }^{5}$ Por. Zapff, Jesus Sirach 25-51, 327.

${ }^{6}$ Prerogatywy związane z przymierzem (nieodwołalna więź z Bogiem) zostają tu przeniesione na dar kapłaństwa związanego z osobą Aarona i jego potomków, por. Wright III, „The Use”, 195.

${ }^{7}$ Por. Reiterer, „Aaron's Polyvalent Role”, 33; Skehan - Di Lella, The Wisdom of Ben Sira, 511.

${ }^{8}$ Marginalia Ms B podają בברכה (w błogosławieństwie). Beentjes (ed.), The Book of Ben Sira, 79. Reiterer, (,Aaron's Polyvalent Role”, 34) uważa, iż jest to bardziej oryginalna lekcja, gdyż odnosi się do sedna posługi kapłańskiej - przekazywanie błogosławieństwa (życia) Boga.

${ }^{9}$ Por. Zapff, Jesus Sirach 25-51, 328; Sauer, Jesus Sirach, 310; Skehan - Di Lella, The Wisdom of Ben Sira, 511.

${ }^{10}$ Por. Reiterer, „Aaron's Polyvalent Role”, 35-36. 
(תועפות ראם), jako do jednego z elementów stroju arcykapłana. Jest to metafora mocy i siły, która w Lb 23,22 i 24,8 przynależy do samego Boga, wyprowadzającego swój lud z Egiptu. Kapłan będzie więc obleczony w moc i piękno Boga (45,8a). Mędrzec wymienia też różne elementy stroju arcykapłana: spodnie, tunikę, efod $(45,8 b)$, ozdoby szaty (jabłka granatu i dzwoneczki: 45,9a), purpurową szatę $(45,10 \mathrm{a})$, woreczki z urim i tumim $(45,10 \mathrm{~b})$, kamienie upamiętniające dwanaście pokoleń $(45,11)$, ozdobioną tiarę $(45,12)^{11}$. Choć elementy stroju pochodzą z Wj 28, to zauważa się dodatki autora wyraźnie wykraczające poza opis arcykapłana i będące oznaką władzy ${ }^{12}$. W ויפארהו Wersji hebrajskiej 45,8b pojawia się wyrażenie

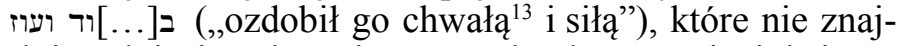
duje odniesień do opisów arcykapłana w Pięcioksięgu. Siła (עוז) natomiast, odnosi się do osoby Dawida (por. 2

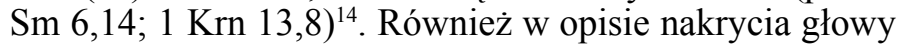
arcykapłana mędrzec używa wyrażenia עטרת פ, które pojawia się tylko jeszcze raz w BH w Ps 21,4 na oznaczenie korony króla. A zatem atrybuty króla zostały w myśli syna Syracha przeniesione na osobę arcykapłana ${ }^{15}$. Strój wzbudzał podziw z powodu swego piękna, a jednocześnie swej unikalności - tylko arcykapłan i jego następcy mogli go włożyć $(45,13)$. Był on więc wyrazem szczególnego Bożego wybrania i posługi, do której został powołany arcykapłan. Opis stroju kończy się odniesieniem do składanych ofiar $(45,14)$, a zatem - do posługi kapłańskiej pełnionej przez Bożych wybrańców ${ }^{16}$. Po opisie stroju arcykapłana mędrzec informuje o wprowadzeniu w czynności kapłań-

${ }^{11}$ Por. Skehan - Di Lella, The Wisdom of Ben Sira, 511.

12 Piwowar, ,Syrach”, 107.

13 Tekst uszkodzony, możliwa rekonstrukcja בכוד (,chwałą”).

${ }^{14}$ Por. Reiterer, „Aaron's Polyvalent Role”, 39.

15 Jezus Syrach spisał swoją historię w jednym określonym celu. Jest nim utrwalenie kapłańskiej sukcesji Szymona i jego następców. Ich rola miała zagwarantować ciągłą aktywność Boga w historii Izraela. Por. Beentjes, „The Countries Marvelled”, 12-13; Wright III, „The Use", 197.

${ }^{16}$ Tekstu Syr 45,9-14 brak w wersji syryjskiej. 
skie Aarona, co dokonało się za pośrednictwem Mojżesza $(45,15)$. Syrach odnosi się tu do Wj 29 i Kpł 8, w których znajduje się opis konsekracji kapłanów (namaszczenie olejem). Jest tu jednak coś więcej. Mędrzec mówi o zawar-

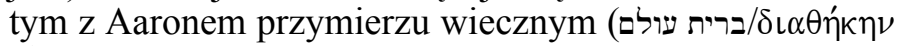

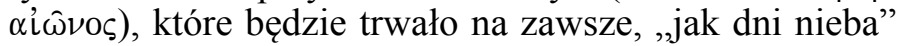
(Syr 45,15: כיפי שמים te z Dawidem (por. Ps 89,30: כיפו שמים oủpavoû). Również błogosławienie ludu w imię Pana przywołuje czynności Dawida (por. $2 \mathrm{Sm} 6,18 ; 1 \mathrm{Krn} \mathrm{16,2)}{ }^{17}$. A zatem znów atrybuty króla zostały w myśli Syracha przeniesione na osobę arcykapłana. Jednak nigdy w BH nie ma mowy o zawarciu przymierza z Aaronem. Mędrzec w opisie Aarona i Pinchasa posługuje się charakterystyką arcykapłana okresu Drugiej Świątyni. Ukazuje ich jako posiadających zarówno władzę religijną, jak i świecką (ustawodawczą, wykonawczą i sądowniczą) z postanowienia samego Boga $^{18}$. Syr 45,16 wymienia natomiast typowe czynności kapłańskie, które miały być udziałem Aarona i jego następców: zbliżanie się do ołtarza, przedstawianie ofiar, składanie kadzidła i dokonywanie przebłagania za $\operatorname{lud}^{19}$. Według Syr 45,17 arcykapłan otrzymuje misję nauczania, która wyraża jednocześnie jego autorytet i władzę. To, co było, według Syracha, przedmiotem nauczania Aarona, zostanie omówione poniżej, w szczegółowej analizie 45,17. Ostatnia cześć pochwały Aarona dotyczy historii buntu Koracha i jego popleczników opisanego w Lb 16. Tam jednak podmiotem działania jest Mojżesz. Bunt jest skierowany początkowo przeciwko niemu (Lb 16,2), następnie pojawia się również odniesienie do Aarona (Lb 16,3). Jest to jednak bunt przeciwko samemu Bogu (Lb 16,11), dlatego Mojżesz przeprowadza próbę, która ma wykazać, kogo wybrał Bóg. W opisie Lb 16 Aaron nie jest głównym bohaterem opowiadania, staje się nim jed-

${ }^{17}$ Por. Reiterer, „Aaron's Polyvalent Role”, 48.

${ }^{18}$ Piwowar, „Syrach”, 107.

${ }^{19}$ Por. Reiterer, „Aaron's Polyvalent Role”, 48; Wright III, „The Use", 199. 
nak w interpretacji tego wydarzenia przez Syr 45,18-22 20 . Syrach przypomina o nieodwołalnym Bożym wybraniu Aarona i jego potomków oraz przestrzega przed próbą bezprawnego przejęcia jego roli ${ }^{21}$. Sam Bóg jest więc gwarantem autorytetu prawowiernego arcykapłana, zapewniając mu, pomimo braku ziemi, utrzymanie ze składanych ofiar. Opis postaci Aarona w Syr 45,6-22 eksponuje oczywiście postać tego arcykapłana, ukazując genezę jego godności i elementy posługi, ale ma przede wszystkim zwrócić uwagę na znaczenie arcykapłana w czasach Syracha. Cała Pochwała ojców zmierza do ,ukoronowania”, jakim jest tekst sławiący arcykapłana Szymona (50,1-24), a wspomnienie Aarona stanowi historyczną motywację do ugruntowania niepodważalnej pozycji arcykapłana.

${ }^{20}$ Por. Reiterer, „Aaron's Polyvalent Role”, 51.

${ }^{21}$ Czas poprzedzający i towarzyszący początkom rządów Hasmoneuszy wiązał się z silną rywalizacją o urząd jerozolimskiego arcykapłana. Problem rozpoczął się dużo wcześniej, kiedy arcykapłan Oniasz II (220-260 przed Chr.) odmówił płacenia podatków Ptolemeuszom. Pod wpływem takiej niesubordynacji odebrano mu władzę świecką, którą przekazano Józefowi z rodu Tobiadów. Po przejęciu władzy przez mających poparcie u arcykapłanów Seleucydów początkowo panował spokój, a ludność żydowska cieszyła się pewnymi przywilejami. Arcykapłan Szymon II otrzymał odpowiednie zezwolenia na przeprowadzenie koniecznych remontów świątyni, a personel świątynny został zwolniony z płacenia podatków. Podczas urzędu kolejnego arcykapłana, Oniasza III, doszło jednak do licznych napięć i konfliktów z Seleucydami, które zakończyły się śmiercią wygnanego arcykapłana. Wcześniej jego brat Jazon podstępnie przejął urząd, przepłacając Antiocha IV Epifanesa, co przyczyniło się do wzrostu hellenizacji społeczności żydowskiej. W 172 r. przed Chr. nastąpiło obalenie Jazona, a jego miejsce zajął jeszcze bardziej progrecki Menelaos, należący jedynie do niższych szczebli kapłańskich. Po pewnym czasie Jazon powrócił i doszło do zaciętej walki o urząd arcykapłana, co wzmogło krwawe zamieszki i jeszcze utwierdziło pozycję Menelaosa. Były to wydarzenia, które w pewnej mierze przyczyniły się do wybuchu powstań machabejskich, a jednocześnie nadszarpnęły autorytet arcykapłanów jerozolimskich. Por. Pudełko, „Pochodzenie Samarytan”, 184-185. 


\section{Wersje tekstualne Syr $\mathbf{4 5 , 1 7}$}

W wersjach tekstualnych Syr 45,17 zauważa się różnice. Wers $45,17 \mathrm{a} \mathrm{w}$ wersji hebrajskiej ${ }^{22}$ i syryjskiej ${ }^{23}$ jest jednakowy. „(Bóg) dał mu (Aaronowi) przykazania”:

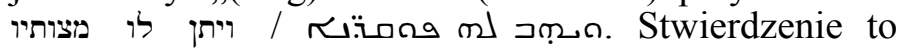
odnosi się faktycznie do Mojżesza, który otrzymał od Boga Prawo (התורה) i przykazania (המצוה) (Wj $24,12)^{24}$. Syrach przenosi więc funkcję pośrednika Prawa na Aarona. Według hebrajskiej i syryjskiej wersji $45,17 \mathrm{~b}$ Aaron otrzymuje władzę nad przepisem i pra-

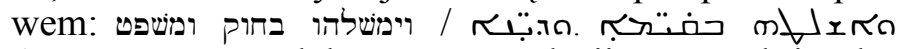
Aaron ma zatem dokonywać regulacji prawnych i sądowych. W Wj 15,25 znajduje się opis pierwszych etapów wędrówki Izraela po wyjściu z Egiptu. Po uzdrowieniu חק ומשפט (,przepis i prawo”; 15,25b). Tekst ten jest jednak nieco kłopotliwy, gdyż nie ma w nim podmiotu, stąd brak jasności, kto ustanawia przepis i prawo ${ }^{25}$. $Z$ jednej strony może się wydawać, że tylko Bóg, co odzwierciedlają liczne przekłady, dodając w tym miejscu imię Boga. To by jednak wskazywało, iż Izrael otrzymał od Boga Prawo już wcześniej niż na Synaju, a to uderzałoby w wiekową tradycję i podstawę synajskiego przymierza. Teksty mówiące o nadaniu Izraelowi przepisów i praw używają tych terminów w liczbie mnogiej: חקים ומשפטים (zob. np. Kpł 26,46; Pwt 4,5.5.8; 5,1; 6,1; 11,32; 12,1). Wyrażenia te, użyte w liczbie pojedynczej, być może odnoszą się do ludzkich postanowień i wyroków. Może więc są to regulacje samego Mojżesza ${ }^{26}$.

${ }^{22}$ Tekst hebrajski według Beentjes, The Book of Ben Sira, 80.

${ }^{23}$ Tekst syryjski według Calduch-Benages - Ferrer - Liesen, $L a$ Sabiduría del Escriba, 247.

${ }^{24}$ Por. Reiterer, „Aaron's Polyvalent Role”, 49.

${ }^{25}$ Zob. Pudełko, „JHWH - Twój Lekarz (Wj 15,22-26)”, 473.

${ }^{26}$ Józef ustanowił przepis (חק) w Egipcie (Rdz 47,26); Jozue ustanowił ludowi przepis i prawo (חק ומשפט) w Sychem (Joz 24,25); Dawid ustanowił przepis i prawo (חק ולמשפט) trwające od tego dnia na przyszłość (1 Sm 30,25). Być może więc w Wj 15,25 chodzi tu o rzeczywiste 
Według Ml 3,22 Bóg przekazał Mojżeszowi przepisy i prawa (חקים ומשפטים) dla Izraela. Aaron nigdzie w Pięcioksięgu nie ustanawia przepisów i praw ani nimi nie zarządza. Jednak możliwe, iż 45,17cd dopełnia rozumienia hebrajskiej wersji 17b (tekst syryjski 45,17 kończy się w tym miejscu). Syr 45,17cd w wersji hebrajskiej odnosi się do pouczania ludu przez Aarona odnośnie do przepisu i prawa: וילמר את עמו חק ומשפט את בני ישראל (,I nauczał swój lud przepisu i prawa synów Izraela”). A zatem „mieć władzę nad przepisem i prawem" może oznaczać nauczanie otrzymanych postanowień27. Była to funkcja Mojżesza, którą otrzymał od Boga wobec ludu, aby ,pouczać was przepisów i praw": ללמד אתכם חקים ומשפטים (Pwt 4,14). Jednak według Pwt nauczanie ludu było również zadaniem pochodzących z pokolenia Lewiego kapłanów: יורו משפטיך ליעקב תורתך לישראל (Niech uczą Twoich nakazów Jakuba, a Twoich praw Izraela") (Pwt 33,10; por. Pwt 17,8-12; 2 Krn 35,2-3; Ml 2,7). Jednak Syrach nie przypisuje tego zadania wszystkim członkom pokolenia Lewiego, lecz jedynie Aaronowi i jego potomkom, co może być wyrazem jego osobistych preferencji ${ }^{28}$.

Nieco inaczej wygląda tekst grecki. W 17a pojawia się odniesienie do przykazań, ale są one tutaj ,instrumentem” otrzymanego od Boga autorytetu i władzy Aarona: " $€ \delta \omega \kappa \in V$

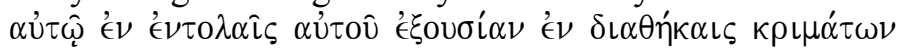

pouczenia Mojżesza, który zorientował się w pojawiających się już od początku marszu trudnościach. Bunty i szemranie ludu wprowadzało chaos i wyraźnie utrudniało wędrówkę w tak niesprzyjających warunkach pustynnych. Choć były one przekazane przez Mojżesza, stanowiły jednak wolę samego JHWH, który w ten sposób przygotowywał swój lud do przyjęcia Tory. Być może więc ,prawo i przepis” to pewne „zasady podróżowania", które tu przygotowują Izraela do otrzymania Prawa na Synaju. Por. Fretheim, Esodo, 233; Meyers, Exodus, 129; Pudełko, „JHWH - Twój Lekarz (Wj 15,22-26)”, 474.

${ }^{27}$ Por. Reiterer, „Aaron's Polyvalent Role”, 49.

${ }^{28}$ Por. Wright III, „The Use”, 199; Box - Oesterley, „The Book of Sirach", 488; Duesberg - Fransen, Ecclesiastico, 304; Skehan - Di Lella, The Wisdom of Ben Sira, 512. G. Sauer (Jesus Sirach, 310-311) misję pouczania łączy z wyrocznią efodu. 
(,dał mu w swoich przykazaniach władzę, przez przepisy praw" $)^{29}$. Aaron otrzymuje autorytet i władzę ( $\left.{ }^{\prime} \xi \xi o v \sigma i \alpha\right)$. Termin ten nie pojawia się nigdy w odniesieniu do Aarona, ani nawet do Mojżesza czy Dawida. Występuje jednak w Księdze Daniela i w Księgach Machabejskich zarówno w odniesieniu do władzy Boga i Jego pomazańca (zob. np.: Dn 4,17; 7,14 ), jak i króla czy innych osób (zob. np. 1 Mch 1,13; 6,11; 10,6.8.32.35.38; 14,4; 2 Mch 3,6; 7,16; Dn 4,$31 ; 6,4 ; 7,12 ; 7,27)$. Interesujące, iż autor 1 Mch używa go dwukrotnie w odniesieniu do arcykapłana: Jonatana (1 Mch 10,38) oraz Szymona (1 Mch 14,4). Wiązało się to $\mathrm{z}$ faktem połączenia władzy religijnej i świeckiej arcykapłanów podczas panowania dynastii hasmonejskiej ${ }^{30}$. A zatem greckie thumaczenie Syracha, które powstało w latach 132-115 przed Chr., uwzględnia zmiany, które dokonały się w Judzie po powstaniach machabejskich. Rządzący Judą kolejni potomkowie Matatiasza, począwszy od Jonatana, łączyli funkcję świeckiego władcy (króla) z posługą arcykapłana. Przeniesienie tego modelu na osobą Aarona jest swoistym anachronizmem, a jednocześnie aktualizacją obrazu arcykapłana, którego pozycja wynikała z powołania otrzymanego przez Aarona od Boga. Władza Aarona, według wersji greckiej, wiąże się zarówno z przykazania-

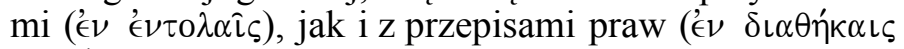
$\kappa \rho \iota \mu \alpha ́ \tau \omega \nu)$. Jest to podobne znaczenie do wersji hebrajskiej (בחוק ומשפט), jakkolwiek rzeczowniki w tekście greckim

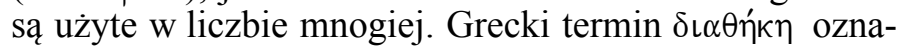

${ }^{29}$ Tekst grecki podaję za Ziegler, Sapientia Iesu Filii Sirach, 338-339.

${ }^{30}$ Gdy w 152 r. wybrano na urząd arcykapłana Jonatana Machabeusza, doszło do połączenia władzy religijnej i świeckiej. Wielu Żydów nie akceptowało Jonatana, uważając, iż arcykapłanem nie może być człowiek splamiony krwią. Połączenie urzędów arcykapłana i króla było jednak kontynuowane. W 141 r. został nim Szymon Machabeusz, a w 134 - Jan Hirkan I. Fakty te ukazują rzeczywisty kryzys urzędu arcykapłana, który nastąpił w czasie poprzedzającym tłumaczenie hebrajskiego oryginału Syna Syracha na język grecki. Nie dziwi zatem interpretacja, której dokonuje wnuk autora. Por. Pudełko, „Pochodzenie Samarytan", 185. 
cza ,przymierze”. Tutaj jednak thumaczy hebrajskie słowo חוק - przepis, nakaz, i tak też powinno być rozumiane ${ }^{31}$. 45,17 cd zawiera, podobnie jak w wersji hebrajskiej, odniesienia do nauczania ludu przez Aarona ${ }^{32}$. Według $17 \mathrm{~cd}$ Aaron ma „nauczać Jakuba świadectw i w Jego Prawie

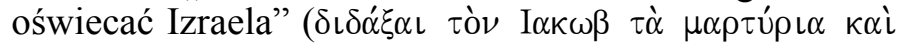

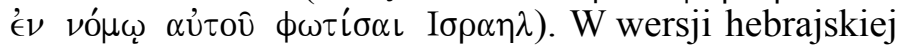
przedmiotem nauczania jest ka zawiera tu termin $\tau \dot{\alpha} \mu \alpha \rho \tau u ́ p \iota \alpha$ (,świadectwa”), liczbę

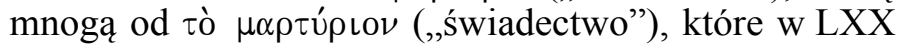
jest thumaczeniem hebrajskiego słowa ערות i jemu podob-

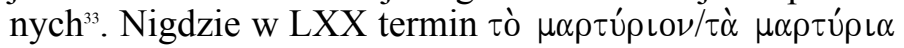
nie thumaczą terminu חקים/ Są w Pwt dwa teksty, które odnosząc się do praw, przepisów, napomnień udzielonych przez Boga za pośrednictwem Mojżesza ludowi, używają terminów: ערות (,świadectwo, napomnienie”), חק (,przepis, dekret”), משפט (,prawo, wyrok"): Pwt 4,45; 6,20. Być może Syrach częściowo posłużył się odniesieniem do tych tekstów, umieszczając terminy חק ומשפט, a tłumacz greckiej wersji zatrzymał się na terminie ערות. Bardziej możliwe jednak jest to, iż Syr 45,17cd stanowi powtórzenie Syr 45,5, gdzie bardzo podobne stwierdzenie zostało zestawione z osobą Mojżesza: ללמר ביעקב חקיי וערותיו ומשפטיו לישראל („Aby nauczać Jakuba Jego przepisów, i Jego świadectw i Jego praw - Izraela") $)^{34}$. W tekście hebrajskim pojawiają się terminy obecne w Pwt 4,45 i 6,20: עדות (,świadectwo,

${ }^{31}$ Por. Minissale, La versione greca, 115.

${ }^{32}$ Smend (Die Weisheit, 434) uważa, iż bardziej oryginalna jest lekcja LXX. Proponuje następujący tekst hebrajski dla Syr 45,17cd: ללמר ליעקב ערותיו ותורתו להורות את ישראל (),Aby nauczać Jakuba Jego świadectw i praw, dla pouczeń Izraela”). Por. Box - Oesterley, „The Book of Sirach", 488.

${ }^{33}$ Termin tò $\mu \alpha \rho \tau$ v́pเov (,świadectwo”) w LXX 129 razy thumaczy

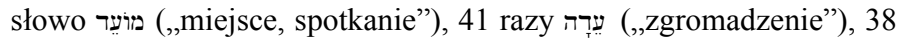

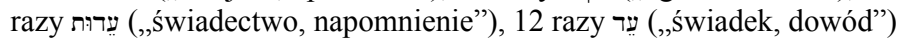
i 1 raz תחערוּדָ (,świadectwo"). Zob. Hatch - Redpath, A Concordance, 896-897.

${ }^{34}$ Beentjes, The Book of Ben Sira, 79. Por. Smend, Die Weisheit, 434; Peters, Das Buch Jesus, 390. 
napomnienie”), חק (,przepis, dekret”), משפט (,prawo, wy-

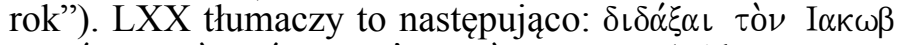

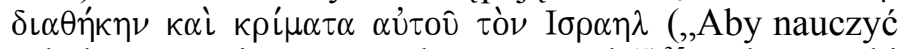
Jakuba prawa i Jego wyroków - Izraela") ${ }^{35}$. Tekst grecki trzy terminy hebrajskie (עדות, עשפט, (משר) zastępuje dwoma: ฑं $\llcorner\iota \alpha \theta \dot{\eta} \kappa \eta$ (,,przymierze, prawo”, zob. wyżej, p. 31) oraz

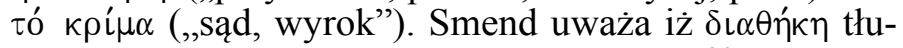
maczy termin ערות zostało opuszczone ${ }^{36}$. Tłumacz, sugerując się w 45,17 podobieństwem z 45,5 umieścił tam

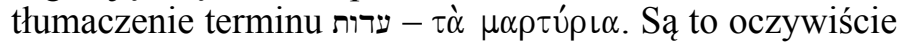
przypuszczenia. Być może tłumacz greckiej wersji dokonał też tu swoistej interpretacji, oddając w 45,17c hebrajskie słowo ח za pomocą greckiego terminu $\tau \dot{\alpha} \mu \alpha \rho \tau u ́ \rho \iota \alpha$.

45,17d zawiera paralelne uzupełnienie wcześniejszego członu. Aaron ma „oświecać w Jego Prawie Izraela” ('€v

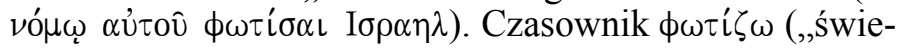
cę, oświecam, objawiam, pouczam") w Księdze Syracha odnosi się do słońca $(42,16)$, gwiazd $(43,9)$, mędrca przez mądrość $(24,32)$ czy samego Boga $(34,17)$. Co ciekawe, metafora świecącej tęczy opisuje postać arcykapłana Szymona $(50,7)^{37}$. Jest to swoisty łącznik pomiędzy postaciami Aarona i Szymona, którzy w godności kapłańskiej doznają wywyższenia, a jednocześnie ich pouczenia oświecają lud na podobieństwo ciał niebieskich. Aby poszerzyć możliwość zrozumienia terminu $\tau \dot{\alpha} \mu \alpha \rho \tau u ́ \rho \iota \alpha$ w Syr 45,17, potrzeba przyjrzeć się użyciu tego terminu w innych tekstach Pisma Świętego.

\section{ZNACZENIE TERMINU $\tau \dot{\alpha} \mu \alpha \rho \tau u ́ \rho l \alpha$ W KONTEKŚCIE ST}

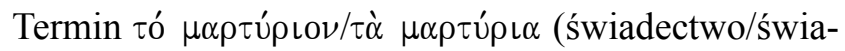
dectwa) pojawia się w historii Mojżesza i Aarona w kontekście kultycznym i prawnym. Namiot Spotkania i Arka

\footnotetext{
${ }^{35}$ Ziegler, Sapientia Iesu Filii Sirach, 336.

${ }^{36}$ Smend, Die Weisheit, 428.

${ }^{37}$ Por. Mulder, Simon the High Priest, 287.
} 
Przymierza wykazują powiązanie ze ,świadectwem”. Namiot Spotkania (אהל מוער) w LXX jest określany Namio-

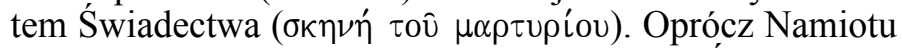
Mojżesz miał wykonać Arkę Przymierza/Świadectwa

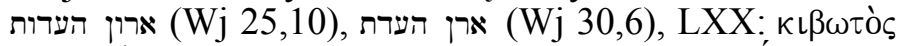

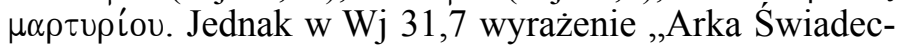

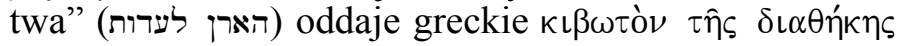
(Arka Przymierza). Pojawia się istotne dla nas użycie terminu ,świadectwo" w liczbie mnogiej: $\tau \dot{\alpha} \mu \alpha \rho \tau u ́ \rho\llcorner\alpha$.

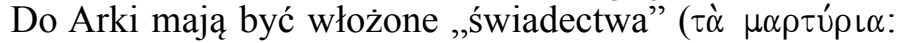
Wj 25,16), które Mojżesz otrzyma od Boga (Wj 25,21). Są

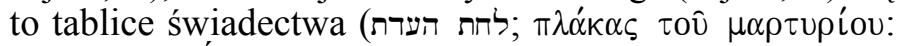
Wj 31,18). „Świadectwa” (הערת; זغ $\mu \alpha \rho \tau u ́ p l \alpha)$ zostają więc złożone w Arce (Wj 40,20). Oznacza to konkretne statuty, przepisy Prawa (Dekalog), dane Izraelowi od Boga. Sam Bóg stał się podmiotem tych ,świadectw”, gdyż potwierdzają one Boże objawienie dane Mojżeszowi, czego wyrazem stały się przykazania ${ }^{38}$. Autorzy biblijni używają więc terminu ,świadectwa" na oznaczenie przepisów, statutów, przykazań, (zob. np. Pwt 4,45; 6,17.20; Ne 9,34; Ps 77,56$)$. $Z$ jednej strony więc mamy do czynienia $z$, ,niematerialnym" znaczeniem tego terminu, w przeciwieństwie do materialnych ,świadectw”, które miały być złożone w Arce Przymierza. Z czasem słowo Boga, Boże prawa, wykroczyły poza słowne przepisy czy zapis na tablicach i stały się księgą. W Pwt położona obok Arki księga Pra-

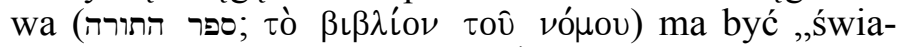
dectwem, świadkiem" (ער; $\mu \alpha \rho \tau$ v́p Izraela (Pwt 31,26). Zachowanie przepisów danych od Boga, ,świadectw”, potwierdzało wierność przymierzu (por. $2 \mathrm{Krl} 23,3$ ). W 2 Krn 23,11 podczas koronacji młody król Joasz otrzymuje koronę oraz ,świadectwa” (הערת; $\tau \dot{\alpha} \mu \alpha \rho \tau u ́ p\llcorner\alpha ; 2$ Krn 23,11). Był to prawdopodobnie zwój Prawa symbolicznie wręczany królowi, aby w swoich rządach stał na straży przymierza Izraela z Bogiem. Mógł to

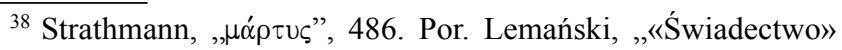
('е̄êtu)", 48. 
być fragment Tory ${ }^{39}$ lub nawet dokument potwierdzający rządy $^{40}$. Ps 118 (LXX) aż 22 razy wymienia termin $\tau \grave{\alpha}$ $\mu \alpha \rho \tau u ́ \rho\llcorner\alpha$, który jest thumaczeniem hebrajskiego ערות. Jest to wyraźne odniesienie do Bożego Prawa (Tory), które jest tutaj napomnieniem, regułą zapewniającą szczęśliwe życie. Niewierność świadectwom sprowadza nieszczęście, klęskę, czego najlepszym wyrazem był najazd Babilończyków i zburzenie Jerozolimy: „Za to, że składaliście ofiary kadzielne i grzeszyliście przeciw Panu, że nie słuchaliście głosu Pana i nie postępowaliście zgodnie z Jego Prawem, Jego przykazaniami i Jego rozporządzeniami (Jr 51,23

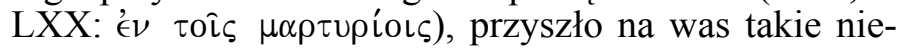
szczęście, jakie trwa dzisiaj" (Jr 44,23 BT). Jeremiasz uwypukla problem niewierności Bogu, co wyrażało się w grzechach bałwochwalstwa, które posiadały charakter kultu ofiarniczego. W $2 \mathrm{Krl}$ 17,15a termin $\tau \dot{\alpha} \mu \alpha \rho \tau u ́ p \iota \alpha$ thumaczy dwa terminy hebrajskie חקית (,przepisy”) (,przymierze”), w wersji greckiej oznacza zawarte z Bogiem przymierze, które zostało przez Izraela złamane. Czy zatem ,'świadectwa" to jakiś konkretny przedmiot czy treść? Przytoczone tu teksty biblijne wskazują na obydwie możliwości. J. Lemański zauważa: „Obiekt określany jako «Świadectwo» wydaje się być czymś, co nie będzie już nigdy więcej pokazywane publicznie. $Z$ czasem utożsamiono go z «kamiennymi tablicami - tablicami świadectwa» (Wj 31,18) i zapisanym na nich Dekalogiem (Pwt 10,1-5), widząc w tym swoisty artefakt. Symbolicznie przypomina on Izraelitom, że to, co Bóg miał im do powiedzenia - powiedział przez Mojżesza, a Jego obecność pośród nich nie

39 „Gdy zasiądzie na królewskim swym tronie, sporządzi sobie na zwoju odpis tego Prawa u tekstu kapłanów-lewitów. Będzie go miał przy sobie i będzie go czytał po wszystkie dni swego życia, aby się nauczył czcić Pana, Boga swego, strzegąc wszystkich słów tego Prawa i stosując jego postanowienia, by uniknąc wynoszenia się nad swych braci i zbaczania od przykazań na prawo czy też na lewo, aby długo królował on i synowie jego w Izraelu" (Pwt 17,18-20 BT).

${ }^{40}$ Por. Curtis - Madsen, Books of Chronicles, 428; Thompson, 1-2 Chronicles, 309; Tuell, First and second Chronicles, 191-192; Pratt Jr., 1 and 2 Chronicles, 511. 
zależy od jakiegokolwiek przedmiotu, lecz od wierności Słowu Bożemu" "41. A zatem treścią „świadectw” stają się wymagania wynikające z przymierza. Co wobec tego stanowiło, według Syracha, kompetencje Aarona w przekazywaniu tych wymagań? Mając świadomość, iż mędrzec niejako „zaktualizował” obraz Aarona, przedstawiając go jako arcykapłana okresu Drugiej Świątyni, należy przyjrzeć się więc, co w przekazie Syracha dotyczy kapłanów i ich tożsamości.

\section{Powygnaniowy arcykaplan a znaczenie PRZEKAZU ŚWIADECTWA WEDlug Syr 45,17}

Syr 45,6-22 zawiera bardzo przemyślany sposób prezentacji Aarona. Jest to próba odpowiedzi na różne koncepcje kapłaństwa we wspólnocie powygnaniowej. W Pwt całe pokolenie Lewiego zostaje ,autoryzowane" do przekazu Prawa, pouczania ludu $(33,10)^{42}$. Syrach odnosi ten przekaz wyłącznie do Aarona i jego potomków, co zauważa się w uwypukleniu w jego tekście buntu Koracha (45,18-22). I to właśnie sam Bóg przez Mojżesza oddaje tę władzę Aaronowi. Syrach odczytuje więc Pwt 33,10 w świetle opowiadania o buncie Koracha i jego popleczników (Lb 16). Dla Syracha ten grzech i decyzja woli Boga okazała się o wiele ważniejsza niż opowiadanie o złotym cielcu (Wj 32,1-35; Pwt 9,11-21), uważanym za główny grzech Izraela na pustyni. Kara, która spotkała zbuntowanych lewitów, była o wiele cięższa niż kara ludu tańczą-

${ }^{41}$ Lemański, „, «Świadectwo» ( $\left.\complement_{e} d \hat{u} t\right) », 72$.

42 „Niech nakazów Twych uczą Jakuba, a Prawa Twego - Izraela, przed Tobą palą kadzidło, na Twoim ołtarzu - całopalenia" (Pwt 33,10 BT). Tradycja P (np. Lb 3,9; 16) stawia potomków Aarona ponad Lewitami. Najsilniejsza polemika antylewicka jest obecna w Ez 40-48. Jest tam mowa o lewickiej ,idolatrii” $(44,10-14)$. Jedynie potomkowie Sadoka (potomka Eleazara, syna Aarona) byli prawowiernymi kapłanami. Syrach nie tylko ignoruje kapłaństwo lewitów, ale również wyklucza możliwość kapłaństwa Mojżesza. Por. Olyan, „Ben Sira’s Relationship to the Priesthood", 274-275. 
cego wokół złotego cielca ${ }^{43}$. Powygnaniowi prorocy nie wspominają o Aaronie i jego potomkach (np. Ml 2,4-9; 3,3-4), a raczej o synach Lewiego. Autorytet należy do synów Lewiego, a Aarona łączy się z grzechem złotego cielca (Pwt 9,20-21) ${ }^{44}$. Ezechiel wspomina o synach Sadoka (43,18-27; 44,15-31; por. Pwt 18,1-5; 33,8-11), jedynych prawowiernych kapłanach, o czym Syrach wydaje się, jednak tylko pozornie, nie wspominać. Pochwała Aarona nie zmierza bowiem w kierunku jego synów, ale łączy się z pochwała jego wnuka Pinchasa $(45,23-25)$. To on jest bezpośrednim poprzednikiem sławionego na końcu arcykapłana Szymona. W genealogii kapłańskiej Pinchas nie ma braci (1 Krn 5,29-30), a zatem wszyscy potomkowie Sadoka byli również ,synami Pinchasa" ${ }^{45}$. Podkreśla to hebrajski dodatek do Syr 50,24, według którego arcykapłan Szymon ma wypełnić przymierze zawarte $\mathrm{z}$ Pinchasem. Przez wzgląd na jego gorliwość o czystość wiary Bóg zawarł z nim i jego potomstwem przymierze wieczne (por. Lb 25,12-13; Syr 45,25) ${ }^{46}$. W zamyśle Syracha zauważa się zatem połączenie: Aaron - Pinchas - Szymon ${ }^{47}$. Aaron

${ }^{43}$ Por. Rivkin, „Ben Sira”, 98*.

44 Według Pwt wszyscy lewici są kapłanami. Podobnie Jr 33,18. W Jr 33,21 czytamy o przymierzu JHWH z Dawidem i lewitami. Jest to kontrast do tradycji kapłańskiej (P) i „Aaronowego ekskluzywizmu”. Podobnie i nauczanie powygnaniowego Malachiasza, w którym mowa jest o przymierzu z Lewim $(2,4.5 .8 .10 .14 ; 3,1)$. Według Ksiąg Kronik Aaronidzi są kapłanami, a Lewici - ich sługami. Por. Olyan, „Ben Sira’s Relationship to the Priesthood", 273.

${ }^{45}$ Nie jest zatem przekonywające, iż Syrach eksponuje zasadniczo Aarona i jego potomków, jak uważa Olyan (,Ben Sira's Relationship to the Priesthood”, 285-286) oraz Wright III (,Fear the Lord and Honor”, 194-195). Choć w jakimś sensie uwypukla źródło kapłańskiego autorytetu, jakim było powołanie Aarona, to czyni to w celu umocnienia pozycji współczesnych sobie kapłanów.

46 ויקם לו ברית פינחס. Beentjes (red.), The Book of Ben Sira, 90. Odniesienia do przymierza z Pinchasem brak w wersji greckiej. Być może był to skutek kryzysu kapłaństwa przez obecność arcykapłanów hasmonejskich. Por. Boccaccini, „Where does Ben Sira Belongs?”, 31-32.

${ }^{47}$ Nazywanie prawowiernych kapłanów „synami Sadoka” było popularne zaraz po powrocie z wygnania, opierając się na proroctwie 
przejmuje od Mojżesza autorytet posługi kapłańskiej i nauczania, co ostatecznie staje się prerogatywą Szymona i prawowiernych arcykapłanów.

Syrach wskazuje, iż Pięcioksiąg (Tora) jest jedynym objawieniem, jakie Bóg przez Mojżesza przekazał Izraelowi (Syr 45,1-2.3b.5). Centrum objawienia jest jednak Aaron, który posiada pełny autorytet w przekazie Bożego objawienia. W czasach Syracha, oprócz kapłanów, działają też pisarze, pobożni soferim, którzy w przyszłości utworzą stronnictwo faryzejskie. Byli związani z Torą i poszukiwaniem mądrości. Syrach zdaje się doskonale łączyć obydwie grupy (Syr 38,24-39,11), a nawet staje się swoistym „mediatorem” między elitą kapłańską a pisarzami-mędrcami. Jest również tym, który wyjaśnia i przekazuje ludowi kapłańską interpretację Tory. Mediacja i łączność była konieczna, gdyż pisarze częstokroć świadomi swej wiedzy i autorytetu popadali w konflikty $\mathrm{z}$ kapłanami ${ }^{48}$. Syrach uwypukla pierwszeństwo kapłanów w wykładzie Tory poprzez prezentację Aarona jako nauczyciela przepisów/świadectw. To właśnie prawowierny arcykapłan jest strażnikiem przymierza. Nie ma już Arki Przymierza, spisanych tablic Prawa ani znaku przymierza, jakim był król z dynastii Dawida. Pozostała Księga Prawa i świątynia jako gwarantujący wierność przymierzu odpowiednik świadectwa. Stąd Aaron jako „nauczyciel świadectw” to obraz misji kapłanów, a zwłaszcza arcykapłana, skoncentrowanej na zachowaniu więzi ludu wybranego z Bogiem. Potwierdza to inny tekst księgi, ukazujący niepowtarzalną bliskość między Bogiem a Jego kapłanami. W Syr 7,29-3149 zauważa się ciekawy paralelizm. Mędrzec wzywa do miło-

Ez 44,15. Jednak później, w II w. przed Chr., to Pinchas stał się ,patronem" sadokickiego kapłaństwa. Nawet ideologia machabejska porównywała gorliwość Matatiasza z Pinchasem (1 Mch 2,26.54). Por. Boccaccini, „Where does Ben Sira Belongs?”, 31.

${ }^{48}$ Por. Rivkin, „Ben Sira”, 100*; Wright III, „Fear the Lord and Honor", 196.

49 „Z całej swej duszy czcij Pana i szanuj Jego kapłanów! Z całej siły miłuj Tego, co cię stworzył, i nie porzucaj sług Jego ołtarza! Bój się Pana i oddawaj cześć kapłanowi, oddaj cześć mu należną, jak ci nakaza- 
ści Boga i szacunku wobec Jego sług - kapłanów. Oprócz paralelnego zestawienia, które stawia wręcz na równi i warunkuje obie postawy, pojawia się jeszcze inny zabieg retoryczny. Tekst zawiera wyrażenia obecne w modlitwie Shema Israel (Pwt 6,4): „z całego serca”, „ze wszystkich sił", co nadaje niezwykłą wagę wezwaniu mędrca. Miłość Boga, najważniejsze przykazanie Prawa, realizuje się w szacunku, trosce, uznaniu autorytetu Jego kapłanów ${ }^{50}$. Arcykapłan Świątyni Jerozolimskiej poprzez szczególny i nieodwołalny wybór Boga posiadał z Nim wyjątkową więź, a zarazem świadomość świętości Boga. Stąd nauczanie świadectw to nie tylko przekaz prawdy o przymierzu, ale bycie widocznym znakiem tego przymierza.

\section{Bibliografia}

Beentjes P.C. (red.), The Book of Ben Sira in Hebrew. Text Edition of All Extant Hebrew Manuscripts and a Synopsis of All Parallel Hebrew Ben Sira Texts (VT.S 68; Leiden - New York - Köln: Brill, 1997).

Beentjes P.C., „The Countries Marvelled at You. King Salomon in Ben Sira 47,12-22", Bijdragen 45 (1984) 6-14.

Boccaccini G., „Where does Ben Sira Belongs?”, Studies in the Book of Ben Sira (red. G.G. Xeravits) (Leiden: Brill, 2008) 21-41.

Box G.H. - Oesterley W.O.E., „The Book of Sirach”, The Apocrypha and Pseudoepigrapha of the Old Testament with Introductions and Critical and Explanatory Notes to

no: pierwociny z ofiary przebłagalnej, dar łopatek z ofiary oczyszczenia i pierwociny rzeczy świętych" (tłum. BT).

${ }^{50}$ Wprawdzie Pięcioksiąg posiada przepisy regulujące części ofiar należące do kapłanów (por. Lb 18,20; Pwt 18,18; Kpł 6,10; 7,34), ale nigdzie nie zostaje ukazana tak ścisła więź między Bogiem i Jego kapłanami. Por. Olyan, „Ben Sira's Relationship to the Priesthood”, 265266; Wright III, „Fear”, 193. Sawyer („Was Jeshua Ben Sira a Priest?”, 65-72) uważa, iż szczególna atencja mędrca wobec kapłanów wynikała $\mathrm{z}$ tego, iż sam był kapłanem i mędrcem jednocześnie. 
the Several Books (red. R.H. Charles) (Oxford: University Press, 1913) I, 268-517.

Calduch-Benages N. - Ferrer J. - Liesen J. (red.), La Sabiduría del Escriba. Edición diplomática de la version siriaca del libro de Ben Sira según el Códice Ambrosiano, con tracucción española e inglesa / Wisdom of the Scribe. Diplomatic Edition of the Syriac Version of the Book of Ben Sira according to Codex Ambrosianus, with Translations in Spanish and English (Biblioteca Midrásica 26; Estella: Editorial Verbo Divino, 2003).

Curtis E.L. - Madsen A.A., Books of Chronicles (International Critical Commentary; Edinburgh: T\&T Clark, 1910).

Duesberg H. - Fransen P.I., Ecclesiastico (Genova: Marietti, 1966).

Fretheim T.E., Esodo (Torino: Claudiana, 2004).

Hatch E. - Redpath H.A., A Concordance to the Septuagint and the other Greek versions of the Old Testament (Including the Apocryphal Books) (Grand Rapids: Baker Academic, ${ }^{2}$ 1998). Lemański J., „«Świadectwo» ( $\check{e} d \hat{u} t$ ) w kapłańskiej koncepcji sanktuarium i przymierza", Verbum Vitae 27 (2015) 47-76. Meyers C., Exodus (The New Cambridge Bible Commentary; Cambridge: Cambridge University Press, 2005).

Minissale A., La versione greca del Siracide. Confronto con il testo ebraico alla luce dell'attività midrascica e del metodo targumico (AnBib 133; Roma: Biblical Institute Press, 1995).

Mulder O., Simon the High Priest in Sirach 50. An Exegetical Study of the Significance of Simon the High Priest as Climax to the Praise of the Fathers in Ben Sira's Concept of the History of Israel (Supplements to the Journal for the Study of Judaism 78; Leiden: Brill, 2003).

Olyan S.M., „Ben Sira's Relationship to the Priesthood”, $\mathrm{Ha}$ rvard Theological Review 80 (1987) 261-286.

Piwowar A., „Syrach - obrońca prawowitego arcykapłana”, Od Melchizedeka do Jezusa Arcykapłana. Biblia o kapłaństwie (red. D. Dziadosz) (ABL 5; Lublin: Wydawnictwo KUL, 2010) 93-117.

Pratt Jr. R.L., 1 and 2 Chronicles (A Mentor Commentary; Fearn: Mentor, 2006). 
Pudełko J.J., „JHWH - Twój Lekarz (Wj 15,22-26)”, „Przeznaczyteś nas dla Twojej prawdy" (4Q 495). Księga pamiątkowa dla dr. Zdzisława J. Kapery w 65. rocznicę urodzin (red. W. Chrostowski) (Warszawa: Vocatio, 2007) 469-480. Pudełko J.J., ,Pochodzenie Samarytan z ich obraz w Syr 50,25-26”, Warszawskie Studia Teologiczne 28/1 (2015) 168-187.

Reiterer F.V., „Aaron's Polyvalent Role”, Rewriting Biblical History. Essays on Chronicles and Ben Sira in Honor of Pancratius C. Beentjes (red. J. Corley - H. van Grol) (Deuterocanonical and Cognate Literature Studies 7; Berlin New York: Walter de Gruyter, 2011) 27-56.

Rivkin E., „Ben Sira - The Bridge Between the Aaronide and Pharisaic Revolutions", Eretz-Israel 12 (1975) 95*-103*.

Sauer G., Jesus Sirach / Ben Sira (ATD Apokryphen 1; Göttingen: Vandenhoeck \& Ruprecht, 2000).

Sawyer J.F., „Was Jeshua Ben Sira a Priest?”, Proceedings of the Eighth World Congress of Jewish Studies. Division A, The Period of the Bible (Jerusalem: World Union of Jewish Studies, 1982) 65-72.

Skehan P.W. - Di Lella A.A., The Wisdom of Ben Sira. A New Translation with Notes (AB 39; New York, NY: Doubleday, 1987).

Smend R., Die Weisheit des Jesus Sirach erklärt (Berlin: Georg Reimer, 1906).

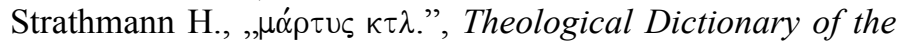
New Testament (red. G. Kittel - G. Friedrich; thum i red. G.W. Bromiley) (Grand Rapids: Eerdmans, 1967, 2006) IV, 474-514.

Thompson J.A., 1-2 Chronicles (The New American Commentary: An Exegetical and Theological Exposition of Holy Scripture 9; Nashville, TN: Broadman \& Holman, 1995).

Tuell S.S., First and Second Chronicles (Interpretation: a Bible Commentary for Teaching and Preaching; Louisville, KY: John Knox Press, 2001).

Witte M., „«Mose, sein Andenken sei zum Segen» (Sir 45,1):

Das Mosebild des Sirachbuchs", Biblische Notizen 107 (2001) 161-186 = Texte und Kontexte des Sirachbuchs. Gesammelte Studien zu Ben Sira und zur frühjüdischen 
Weisheit (Forschungen zum Alten Testament 98; Tübingen:

Mohr Siebeck, 2015) 123-149.

Wright III B.G., ,«Fear the Lord and Honor the Priest». Ben

Sira as Defender of the Jerusalem Priesthood", The Book of

Ben Sira in Modern Research (red. P.C. Beentjes) (Berlin:

Walter de Gruyter, 1997) 189-222.

Wright III B.G., ,,The Use and Interpretation of Biblical Tradition in Ben Sira's Praise of the Ancestors", Studies in the Book of Ben Sira (red. G.G. Xeravits) (Leiden: Brill, 2008) 183-207.

Zapff B.M., Jesus Sirach 25-51. Kommentar zum AT mit der

Einheitsübersetzung (Die Neue Echter Bibel 39; Würzburg:

Echter, 2010).

Ziegler J. (red.), Sapientia Iesu Filii Sirach (Septuaginta: Vetus Testamentum graece auctoritate Societatis Göttingensis editium, 12/2; Göttingen: Vandenhoeck \& Ruprecht, 1965, 21980).

\section{Jolanta Judyta Pudetko PDDM \\ ul. Żytnia 11 \\ 01-014 Warszawa \\ judyta.pd@gmail.com}

Siostra Jolanta Judyta PudeŁko należy do Zgromadzenia Sióstr Uczennic Boskiego Mistrza (PDDM) i jest doktorem teologii biblijnej Uniwersytetu Kardynała Stefana Wyszyńskiego w Warszawie (2006) oraz wykładowcą Papieskiego Wydziału Teologicznego w Warszawie. W latach 2007-2010 studiowała w Studium Biblicum Franciscanum w Jerozolimie, gdzie uzyskała licencjat z nauk biblijnych i archeologii. Autorka książki Wierny przyjaciel lekarstwem życia (Syr 6,16). Koncepcja przyjaźni w Księdze Syracydesa (RSB 28; Warszawa: Vocatio, 2007) oraz kilkudziesięciu artykułów o charakterze naukowym i popularnonaukowym. Jest również zaangażowana w duszpasterstwo biblijne i popularyzowanie lectio divina. Członkini zwyczajna Stowarzyszenia Biblistów Polskich i przewodnik grup pielgrzymkowych w Ziemi Świętej. 
